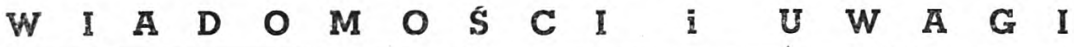

\section{W SPRAWIE LITURGII WIELKIEJ SOBOTY}

Celem niniejszego artykułu jest przede wszystkim zdać sprawę $z$ próby odnowienia pierwotnej liturgii Wielkanocnej dokonywanych na terenie jednego kościoła parafialnego. Próby te zgodnie z zaleceniami Stolicy Apostolskiej sa czynione od 1951 r. Kościołem zaś o który chodzi, jest kościół św. Floriana w Krakowie. Od pięciu lat liturgia Wielkiej Soboty bywa w nim odprawiana w godzinach wieczornych tego dnia.

Obrzędy zaczynają się o godz. 20 (w 1951 r. zaczęly się już o godz. 18), a więc o tej porze, która instrukcja określa jako najwcześniejszą, gdy chodzi o rozpoczęcie liturgii wigilijnej. Poza kościołem święci się ogień i zapala paschał. Po wejścu do kościoła intonuje diakon trzykrotnie ,Lumen Christi“, wszyscy odpowiadaja „Deo gratias" i kolejno zapalaja od paschału przyniesione świece, tak jak to przewiduje instrukcja ceremonii. Podczas śpiewanego $z$ kolei „Exultet" nie płonie $w$ kościele żadne światło prócz światła owych świec. Dopiero po zakończeniu ,praeconium" zapala się elektryczność.

Lekcje bywaja czytane z ambony przez kapłana, który kieruje uczestnictwem wiernych $\mathrm{w}$ całym obrzędzie. Traktusy po lekcjach wykonują kantorzy. Następująca modlitwę śpiewa celebrans $\mathrm{w}$ ten sposób, że po jego wezwaniu ,oremus" oraz diakona ,flectamus genua" wszyscy przyklękaja i dopiero po chwili na dany przez diakona znak ,levate“ powstaja. Wtedy kapłan śpiewa modlitwę, a wszyscy odpowiadają „Amen". Litanię śpiewa kierujący $\mathrm{z}$ ambony kapłan na przemianę $\mathrm{z}$ całym kościołem. On odśpiewuje wezwanie, a wszyscy odpowiadaja ,miserere nobis“, ora pro nobis" itp. wedle brzmienia w dzisiejszym układzie łacińskim.

Poświęcenie wody przygotowuje nas bezpośrednio do Chrztu św.

Stojąc na stanowisku, ze cała liturgia wigilii wielkanocnej jest ześrodkowana koło tego Sakramentu, dokłada się starań, ażeby ten moment, o którym obecnie mowa, najmocniej został podkreślony. Dlatego to po poświęceniu wody chrzcielnej celebrans udziela w sposób uroczysty Sakramentu Chrztu św. kilku dzieciom. Ten szczęśliwy termin Chrztụ św. zostaje oczywiście z góry 
ustalony z rodzicami. Należy przy tym stwierdzić, że wierni coraz chętniej zgłaszają Chrzest św. na ten termin, podczas obrzędów wielkosobotnich.

W pierwszym roku były trudności z wynalezieniem kandydata, w latach następnych sami rodzice licznie ich zgłaszaja. Ażeby nie przedłużać ceremonii celebrans sam chrzci tylko jedno dziecko, a równocześnie inny kapłan udziela tego sakramentu pozostałym. Wstępna część obrzędu sakramentalnego odbywa się w kuchcie kościoła, po czym celebrans wraz z asysta wprowadza uroczyście katechumenów przez główną nawę. W całym obrzędzie uczestniczą wierni dzięki temu, że kierujący ich uçzestnictwem $\mathrm{z}$ ambony kapłan modli się wraz $\mathrm{z}$ celebransem $\mathrm{w}$ języku ojczystym modlitwami zawartymi w rytuale. Podczas wprowadzania katechumenów do kościoła nie tylko rodzice chrzestni, ale wszyscy zgromadzeni odmawiają "Wierzę w Boga“ i „Ojcze nasz".

Po udzieleniu Chrztu św. i odniesieniu poświęconej wody chrzcielnej do chrzcielnicy, którą w tym dniu przystraja się szczególnie, a w danym momencie błogosławi i okadza, następuje odnowienie przez wszystkich przyrzeczeń na Chrzcie św. uczynionych. Tak to moment liturgii wielkosobotniej stanowi dopełnienie momentu poprzedniego. Udzielony przed chwila jednemu $\mathrm{z}$ maleńkich członków tej wspólnoty duchowej, jaką jest parafia, Chrzest wzbudził we wszystkich zebranych wspomnienie tego samego Sakramentu. Ważne jest przy tym nje samo przypomnienie chwili, tego trudno oczekiwać po doroslych wiernych, którzy Chrzest św. przyjęli w dniach swego niemowlęctwa - ważne jest natomiast uświadomienie faktu duchowej i trwałej przynależności do Chrystusa. To właśnie znajduje swój oddźwięk, i to oddźwięk wyraźny, odczuwalny, w odnowieniu przyrzeczeń na Chrzcie św. uczynionych.

Po odśpiewaniu drugiej części litanii do Wszystkich Swiętych odprawia się Mszę św. Wigilijną. Uczestniczący wierni śpiewają wedle gregoriańskiej melodii „Kyrie“, „Gloria“ i dalsze części stałe Mszy św. Teksty zmienne są odczytywane $z$ ambony. Podejmuje się po lekcji „Alleluja“ i po kantorach, którzy to czynią w języku łacińskim, cały kościół w języku ojczystym śpiewa znany z nieszporów psalm. Podczas Komunii św. wiernych śpiewa się również któryś ze znanych psalmów lub kantyków nieszpornych. Natomiast „Benedictus“ z laudes wielkanocnych, które w tym nowym układzie obrzędów wielkosobotnich zajęły miejsce dawnych nieszporów tego dnia, oraz związane $z$ nim antyfony śpiewają kantorzy. Jest sprawą do dyskusji czy podczas Mszy św. wielkosobotniej i całej ceremonii lud może śpiewać jakiekolwiek inne pieśni prócz psalmów, które z samego układu obrzędów wynikają. 
W tym porządku nabożeństwa, po wprowadzeniu odpowiednich akcentów liturgicznych i stopniowym wykluczeniu wszelkich niepotrzebnych dłużyzn, Msza św. wypada ok. godz. 22, a cała liturgia kończy się około godz. $22^{30}$. Jeśli jeszcze chodzi o samą Mszę św. to wiadomo, że przy pierwotnym przebiegu całego obrzędu wigilijnego wypadała ona nad ranem. Zawiera też w sobie wyraźne akcenty liturgiczne odnoszące się do samego faktu zmartwychwstania, który to fakt ma przed oczy wiernych na nowo postawić. W tej oprawie, w atmosferze budzącego się dnia wczesnej wiosny, Msza św. wigilijna musi posiadać ogromną przekonywującą siłę wyrazu. Należy przyznać, że odprawiana w późnych godzinach wieczornych Wielkiej Soboty wiele $z$ tej siły traci. Wierni przyjmują Komunię św. powracają do swych domostw, by nazajutrz. rano o godz.: $5^{45}$ zgromadzić się na rezurekcję. Sama procesja rezurekcyjna o tej porze gromadzi zgodnie $z$ krakowską tradycją rzesze wiernych. W porównaniu z liczbą uczestniczących poprzedniego wieczoru w liturgii sobotniej jest to liczba o wiele wyższa.

Należy jednak równocześnie stwierdzić, że gdy chodzi o samą wieczorną liturgię Wielkiej Soboty, to znów liczba uczestników w porównaniu z dawniejszymi latami, w których liturgia ta bywała odprawiana $w$ godzinach porannych tego dnia, niepomiernie wzrosła. Jest to jednakże raczej szczególna grupa wiernych. Bardzo wielu z nich uczestniczy w obrzędach przy pomocy mszałów łacińsko-polskich czy też polskich. Zwraca ponad to uwage stosunkowo liczny udział ludzi młodych. Wszystko to zarazem stanowi przejaw rosnącego uświadomienia liturgicznego. Jednym z owoców tego uświadomienia były właśnie prośby skierowane $z$ różnych krajów do odpowiednich czynników w Kościele, by przywrócić liturgii Wielkiej Soboty choć w części, to stanowisko, jakie miała $\mathrm{w}$ pierwszych wiekach chrześcijaństwa, kiedy to jeszcze podczas wigilijnych obrzędów nocy Zmartwychwstania dokonywał się chrzest katechumenów przygotowywanych do tego momentu w ciągu lat próby, a w szczególności w ciągu ostatnich czterdziestu dni Wielkiego Postu.

Równocześnie jednak należy $\mathrm{z}$ całym poczuciem realizmu $\mathrm{w}$ tej dziedzinie ustalić fakt, który po kilku latach pozwala z całą oczywistością stwierdzić, że liczba uczestników procesji rezurekcyjnej wciąż niepomiernie przewyższa liczbę uczestniczących w liturgii wielkanocnej wigilii. Przyczyniają się do tego nie tylko różnorodne zewnętrzne okoliczności wynikające z tradycyjnego sposobu święcenia Wielkanocy w naszym społeczeństwie, przyczynia się do tego przede wszystkim ta ckoliczność, że w poczuciu ogółu naszych katolików, właściwym wyrazem liturgicznym święta Zmartwychwstania jest właśnie obchód rezurekcyjny. Kiedy w 1952 r. na zarządzenie Ks. Arcybiskupa obrzędy wielkopostne we wszystkich 
kościołach krakowskich odbywały się wieczorem i zostały połączone z rezurekcją, wówczas i na terenie kościoła św. Floriana ceremonie odbyły się w taki sam sposób. Stwierdzono wówczas wprawdzie najliczniejszy udział wiernych, jednakże ci wierni w ogromnej większości przyszli przede wszystkim na rezurekcję. W poprzedzających procesję obrzędach uczestniczyli na ogół bez zrozumienia (mimo, że jak zawsze były one prowadzone z ambony). Wyczuwało się poza tym ogólne znużenie, w całości bowiem ceremonie trwały dìużej niż do godz. $23^{00}$.

Tyle, gdy chodzi o część sprawozdawczą. W ciągu tych pięciu lat zdołano zebrać szereg własnych doświadczeń na omawiany temat. Poza tym dochodza informacje o poczynaniach innych kościołów i parafii $\mathrm{w}$ tej dziedzinie. Istnieja przeto podstawy do tego, ażeby nie tylko zdać sprawę $\mathrm{z}$ własnych poczynań, ale również uzasadnić je szerzej, a równocześnie wyciągnać z nich wnioski praktyczne. Wiadomo przecież ,że powrót do pierwotnego sposobu odprawiania liturgii Wielkiej Soboty nosi na razie charakter próby. Należy zatem przyjąć, że wszelkie wypowiedzi na temat przebiegu owej próby i jej wyników, sa jak najbardziej celowe i wskazane. Zasadniczy wniosek można ując w następujący sposób: W tych warunkach, w jakich żyje konkretna parafia św. Floriana, są obiektywine dane po temu, ażeby na stałe przywrócić wigilię paschalną $w$ takim układzie, $w$ jakim to zostało zalecone przez Kongregację w 1951 r. Swoją drogą zaś należy zachować procesję rezurekcyjną. Najważniejszym jednak elementem tego wniosku jest, że należy liturgię wigilijną wyodrębnić od liturgii rezurexcyjnej. Tłumaczy się to przede wszystkim w taki sposób, że wigilijna liturgia Wielkiej Soboty oraz liturgia rezurekcyjna, chociaż wyrastają $z$ tego samego pnia, mianowicie z faktu Zmartwychwstania Pańskiego, to jednak bardzo różnią się od siebie charakterem. Liturgia rezurekcyjna ma za swój przedmiot właściwy samo historyczne zmartwychwstanie Jezusa Chrystusa, przy czym główny akcent jest położony na tym, ażeby zewnętrznie uwydatnić Jego tryumf oraz znaczenie tego tryumfu dla wiary Jego wyznawców. Natomiast liturgia wigilijna ma inny przedmiot właściwy. Jest nim tajemnica wewnętrznego zmartwychwstania czlowieka ze śmierci grzechu do życia łaski, które dokonywa się za sprawą zmartwychwstałego Chrystusa. Historyczny fakt Zmartwychwstania zostaje tu niejako przeniesiony ze swych zewnętrznych wymiarów do skali wewnętrznej. Liturgia nocy Zmartwychwstania skupia całą uwagę nie tyle na fakcie przywrócenia ludzkiego życia martwemu ciału Jezusa Chrystusa, ile na fakcie przywracania Bożego Życia obumarłej duszy ludzkiej. Tajemnica zmartwychwstnia występuje tu- 
taj w pełnej swej analogii. O ile liturgia rezurekcyjna wywołuje w świadomości wiernych fakt Zmartwychwstania jako fundament ich wiary $\mathrm{w}$ Jezusa Chrystusa, to natomiast dawna liturgia wielkanocnej wigilii idzie głębiej, idzie zaś właśnie poprzez tę analogię Życia, które stanowi sam rdzeń tajemnicy Zmartwychwstania.

Tak tedy istnieją niewątpliwie racje do wyodrębnienia obu tych całości liturgicznych. Liturgia Wielkiej Soboty stanowi dla siebie całość, która zaśrodkowuje się wokół Sakramentu Chrztu św. rezurekcja zaś stanowi inną całość: teoforyczna procesja ma dać wyraz tryumfu Chrystusa zmartwychwstałego. Zupełnie inne sa założenia obu tych całości, zupełnie też inny ich styl i nastrój. Obie przy tym są potrzebne. Eącznie bowiem dają pełny obraz liturgiczny zmartwychwstania. O ile w pierwszych stuleciach Kościoła moment wigilijny wyraźnie przeważał, moment zaś rezurekcyjny był tylko dyskretnie zaznaczony poranną Msza św., to taka struktura liturgicznej całości miała pełne pokrycie w życiu ówczesnego Kościoła. Wszakże ta poranna rezurekcyjna Msza św. jest pełna akcentów takiego wewnętrznego uniesienia, których nie zastąpi cały splendor dzisiejszej procesji rezurekcyjnej. Akcenty te jednakże wyczuwalne są dla dusz wewnętrznych, zżytych z tajemnicami liturgii, a na zewnątrz mogą łatwo ujść uwadze. Tymczasem stosownie do ustroju człowieka również i jego wiara szuka sobie obok wewntęrznych uniesień także zewnętrznie mocnych wyrazów i potężnych przeżyć. Te to właśnie dążności znajdują odzwierciedlenie w rezurekcyjnej procesji. I dlatego należy ją zachować w całym blasku. Jeżeli liturgia jest nie tylko formą obiektywnej Tradycji polegającej na przekazywaniu samych prawd, ale również bierze swój kształt z życia całych pokoleń konkretnych chrześcijan, to rezurekcja nosi ten kształt na sobie. Można by zatem sprawę ująć w ten sposób: rezurekcję należy podtrzymać, a do liturgii wielkosobotniej należy na nowo wychowywać współczesnego wyznawce Chrystusa. Jednakże wychowanie stanowi zawsze pewien proces wymagający nakładu czasu i sił.

$\mathrm{Z}$ racji więc merytorycznych wypadałoby raczej oddzielić liturgię wielkopostną, wigilijną, od liturgii rezurekcyjnej. Ich łączenie wydaje się czymś sztucznym. Trzeba tu jeszcze wziąc pod uwagę moment psychologiczny. W pierwszych wiekach obrzęd nocy Zmartwychwstania był chyba czymś podobnym w naszym współczesnym toku życia religijnego do dnia pierwszej Komunii św. Skupiało się na nim ogromnie wiele zainteresowań i oczekiwań. Siłą faktu był on, rzec można atrakcyjny. Sakrament Chrztu św. przyjmowało tej nocy wielu członków gminy chrześcijańskicj, parafii. Pociągało to za sobą $z$ pewnością jakieś uroczystości rodzinne. W obecnej sytuacji te punkty atrakcji i zainteresowania religijnego skupiły się na innych momentach, związały $\mathrm{z}$ innymi dniami $\mathrm{w}$ roku litur- 
gicznym. Brak przeto psychologicznej gotowości domaga się raczej powolnego działania. Trzeba by dopiero powoli za pomoca przemyślanej akcji znów ześrodkować całą uwagę wiemych na tej wspaniałej nocy, przywrócić jej znaczenie centralne i uprzywilejowane, gdy chodzi o całokształt współczesnego życia sakramentalnego. Samo odnowienie przyrzeczeń Chrztu św. w oparciu o Chrzest kilku niemowlat z parafii nie șprawi jeszcze automatycznie, że obrzęd wielkosobotni wyrośnie do tego znaczenia, które miał ongiś.

Dla wielu dzisiejszych chrześcijan liturgia Wielkiej Soboty jest czymś w rodzaju starego pomnika. Formy, od których odeszło w dużej mierze życie religijne współczesnych wyznawców Zmartwychwstałego Chrystusa, chociaż one najwięcej mówią o jego istocie. I wyczuwa się, że niegdyś przed wiekami tutaj się to życie koncentrowało, że pod tymi właśnie kształtami liturgicznymi tętniło najsilniejszym pulsem. Ażeby dzisiaj, po wiekach, mogło się to powtórzyé, w tym celu potrzeba, aby nasze współczesne życie wróciło znów do tych prastarych form, aby skoncentrowało sie pod nimi na nowo. Same bowiem formy liturgiczne się nie przedawniaja dlatego właśnie, że życie, które ongiś je wypełniało, i to, które dzis znów zaczyna je wypełniać, jest to w zasadzie to samo życie. Jeżeli w ciagu stuleci oderwało się ono od tamtych form, a połaczyło z innymi, to fakt taki musiał mieć swoje powody, Jeśli dzisiaj znów, po tylu wiekach, wykazuje wyraźną tendencję do powrotu, do poiączenia się na nowo $z$ tamtymi formami liturgicznymi, to znaczy, że są one nie tylko archaiczne, ale też najlepiej przystosowane do jego przyjęcia.

Zadaniem przeto naszym jest chwytać te odradzające się tendencje, wychodzić im naprzeciw. Trzeba przyznać, że są one wśród nas jeszcze stosunkowo nieśmiałe i niedość uświadomione. Dlatego koniecznym warunkiem odprawiania liturgii wielkosobotniej jest dyskretne kierownictwo i rzetelne przygotowanie obrzędów. Musza być stworzone proste, ale mocne ramy, w których wyznawcy Chrystusa będą mogli przeżywać tajemnicę wewnętrznego, duchowego zmartwychwstania wraz z Nim. Bez takiego dyskretnego pokierowania można oczekiwać uczestnictwa w liturgii Łylko w wyjątkowych wypadkach, a $z$ reguły tylko zniecierpliwienia i nudy.

Najważniejszym zagadnieniem praktycznym i technicznym jest niewątpliwie określenie pory dla całego obrzędu wielkosobotniego. Z wielu względów nadawałaby się pora wieczorna (np. od godz. 20). Trzeba się bowiem liczyć z tym, że znużony pracą człowiek nie łatwo zdobędzie się na to, ażeby na udział w owych ceremoniach poświęcić godziny nocne. Jednakże w bardzo wielu miejscach właśnie godziny wieczorne Wielkiej Soboty zajęte są tradycyjnie przez rezurekcję, w ślad za czym idą też pewne zwy- 
czaje w życiu rodzinnym wiernych. Zupełnie łatwe jest oczywiście rozwiązanie tam, gdzie (jak w kościele św. Floriana) tradycyjnie rezurekicja odbywała się we wczesnych godzinach porannych Wielkiej Niedzieli. Może nawet najwłaściwszą rzeczą byłoby powszechnie dążyć do takiego rozwiązania, ażeby liturgia wigilijna odprawiała się późnym wieczorem Wielkiej Soboty, a rezurekcja w Wielką Niedzielę rano. Z wielu bowiem względów wydaje się rzeczą nieodpowiednią, aby cały oḅrzęd wielkanocny, zarówno wigilijny jak i rezurekcyjny łączyć w jedną całość i odprawiać w Wielką Sobotę wieczorem. I przedstawione powyżej względy natury zasadniczo liturgicznej i wspomniane względy natury psychologicznej przemawiałyby przeciwko temu. Otrzymalibyśmy w rezultacie raczej jakieś natłoczenie akcji liturgicznej, która nie łațo mogłaby zostać właściwie przyjęta i przeżyta.

Jeśli zaś chodzi o przeniesienie całego obrzędu na godziny nocne, to $\mathrm{w}$ takim ujęciu połączenie ceremonii wielkosobotnich (wigilijnych), które wówczas zaczynałyby się około godz. 22 lub 23, z rezurekcją wydaje się już nieco bardziej uzasadnione. Przecież i pierwotna liturgia nocy Zmartwychwstania przechodziła od charakteru wigilijnego do momentu rezurekcyjnego we Mszy św. Można by w ogóle pomyśleć nad tym, czy w naszych warunkach, gdzie ów moment rezurekcyjny dawnej liturgii tak wydatnie został rozbudowany przez procesję rezurekcyjna nie wypadałoby tej Mszy św. wielkosobotniej (a właściwie wedle dawnego porządku nocnej lub też porannej Mszy św. o Zmartwychwstaniu Pańskim), związác z samą rezurekcją. Czy nie byłoby rzeczą bardziej uzasadnioną odprawiać ją bezpośrednio przed procesją rezurekcyjną, $i$ to właśnie przy Bożym grobie. W taki sposób zyskałaby $z$ pewnością wymowa całej jej treści liturgicznej, znalazłby również swoje liturgiczne rozwiązanie tak bardzo zakorzeniony u nas zwycza) Bożego Grobu. Wedle takiej koncepcji ceremonie w Wielka Sobotę wieczorem ograniczałyby się do tej samej treści wigilijnej, przy czym główny akcent spocząłby jak dawniej na Sakramencie Chrztu św. i odnowieniu obietnic chrzestnych. Ceremonie zaś poranne w Wielką Niedzielę miałyby charakter w całości rezurekcyiny, zaczynając się od Mszy św. przy Bożym Grobie, przechodzilyby następnie w ten potężny zewnętrzny akt liturgiczny, jakim jest procesja rezurekcyjna. W takim rozwiązaniu zawierałoby się wyraźne wyodrębnienie obu tych całości liturgicznych, o których mowa była poprzednio. Wielka Sobota pozostałaby jak ongiś w całości wigilią Zmartwychwstania Pańskiego, dniem o tyle aliturgicznym i podobnym do Wielkiego Piątku, że pozbawionym Mszy św Wielka Niedziela natomiast nabyłaby o wiele wydatniej charakteru uroczystości rezurekcyjnej. W razie odprawiania liturgii wi lkopostnej $\mathrm{w}$ godzinach nocnych, należałoby idąc po linii tych 
założeń, które poprzednio zostały podane i częściowo bodaj uzasadnione, wyodrębnić tę liturgię od rezurekcji w ten sposób, żeby się po zakończeniu litanii do Wszystlkich Swiętyeh przenosiło akcję liturgiczną do Bożego Grobu i tam rozpoczynało liturgię rezurekcyjną od Mszy św.

Artykuł niniejszy w pierwszym rzędzie zawiera sprawozdanie z prób zdążających do odnowienia prastarej liturgii wielkopostnej. Ponieważ jednak przy tej sposobności nagromadziła się pewna ilość nie tylko doświadczeń, ale również i przemyśleń, refleksji oraz projektów, dlatego wszystko to pozwalamy sobie podać do wiadomości szerszego ogólu duszpasterzy, a przede wszystkim Najdostojniejszych Księży Biskupów, jako materiał, na którym będzie można oprzeć dalsze, definitywnè już postanowienia w sprawie liturgii Zmartwychwstania Pańskiego.

Kraków

K.S. KAROL WOJTYEA

\section{HISTORIA I PRORLEMY POSTU EUCHARYSTITCREGO}

Uwagi niniejsze nie są oryginalnym ujęciem problemu postu. eucharystycznego; opierają się wylącznie na pracy ks. dra Jana Piekoszewskiego pt. "Le jê̂ne eucharistique" i są rekapitulacją jej osiągniẹć i wyników w tej dziedzinie.

Dlatego też jest zachowany tok myśli wspomnianego autora podobnie, jak ta rozprawa, dzieli się nasz szkic na dwie częśc: pierwsza traktuje o poście eucharystycznym w jego rozwoju historycznym, d $\mathrm{r} u \mathrm{~g}$ a zajmuje się postem eucharystycznym w obliczu problemów ostatnich lat.

Na samym wstępie należy zaznaczyć, że trudno powiedzieć kiedy przestrzeganie postu eucharystycznego stało się prawem i obowiazkiem. Chrystus bowiem ustanowiwszy Eucharystię, udzielal Jej Apostolom w trakcie uczty, tak że pewnym jest, iz Oni nie zachowali postu. Praktyka przestrzegania postu naturalnego ustaliła się w ciągu rozwoju historycznego życia chrześcijaństwa.

Jeżeli Chrystus udzielił Komunii św. Apostołom nie będącym na czczo, to nie wrnika z tego, że Kościól pragnąc przestrzegać postu eucharystycznego jest w kolizji z wolą Chrystusa, ponieważ Jezus ustanawiając pamiątke Swej Męki nie dyktował żadnego prawa, ani nie określał jakiegoś rytuału. Sprawy te pozostawił do rozstrzygnięcia Apostołom i Swojemu Kościołowi.

Kościół rytuału, przynajmniej za Apostołów, rie określił, idąc wiernie za tradycją ostatniej Wieczerzy. Eamanie Chleba lączyło się z ucztą.

Na pytanie, co miało u pierwszych chrześcijan pierwszeństwo w czasie: Agape czy Eucharystia? - pisarze Kościoła dają różną 